\title{
Case-study of the Role of Environment as an Energy Externality in Geneva Vineyard Cultivation and Wine Production
}

by

\author{
Gonzague Pillet, D.E.(Fribourg) \\ Research Economist, Centre for Human Ecology \\ and Environmental Sciences, \\ University of Geneva, 1211 Geneva 4, Switzerland.
}

\section{INTRODUCTION}

Analysis of economic effects upon the environment is common practically throughout modern scientific literature. In contrast with this situation, the environmental role in specific economic activities is rather little appreciated or even understood. Consequently, economics is only beginning to build efficient tools to deal with such environmental, 'external' contributions. In general, environmental conservation is a topic with which only the most farsighted among industrialists and economists are as yet concerned.

The aim in this paper is to indicate how to develop applied environmental economics by means of a case-study, that of Switzerland's Geneva Canton vineyard cultivation and wine production. The general framework of the study is composed of systems ecology (Odum, 1983), energy analysis procedure (Odum \& Odum, 1983), and energy externality analysis (Pillet \& Odum, 1984, 1987). Accordingly, the focus here is on the energy analysis of the environmental role, and the measurement of the energy externality in an economic subsystem - by means of an energy analysis overview of the Geneva vineyard cultivation, and further processing of the product to wine with due featuring of the typical energy externality.

First, inputs and products of a representative agro-ecosystem are portrayed with the use of energy circuit language, details concerning the evaluation procedure being duly pointed out. Then, the environmental role in the Geneva wine industry is analysed, including service inputs. Energy externalities are evaluated, and results are discussed by means of indices and inferences.

\section{General Design of Agro-ECOSYSTEMS AND ENERGy ANALYSIS PROCEDURE}

The inputs and products of any representative agricultural production process are generally portrayed as in Fig. 1, combining direct solar energy, wind, rain, soil, fuel and electricity, irrigation water, pesticide, nutrients, seed, land, labour, and capital, to yield products and by-products of food and fibre. All flows are arranged from left to right in the order approximately of their increasing solar transformity (quality).

Yet, if we want to represent agricultural production in the broader context of some general agro-ecosystem (or of the web of energy transformation processes in which it is embedded), energy diagramming leads to some moderately complex inventory diagram such as that shown in Fig. 2. Agricultural production is displayed within energy trans-

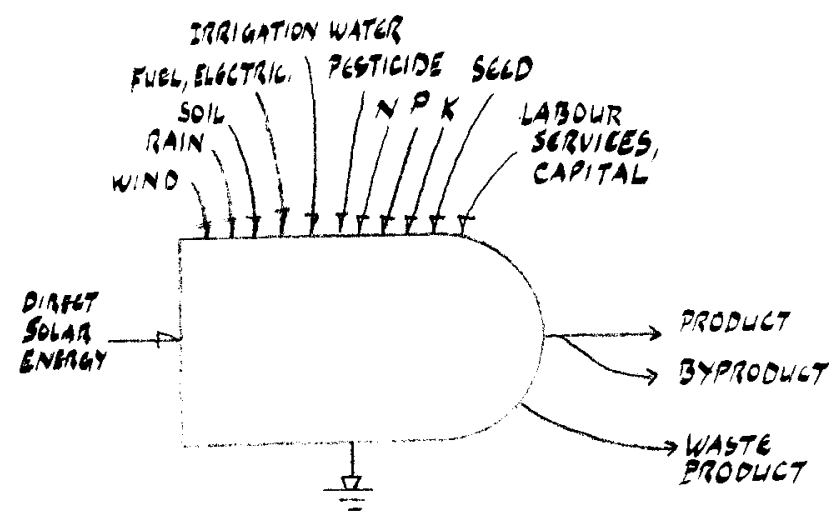

FIG. 1. Agricultural inputs arranged in order of their solar transformity. Adapted from Odum (1984).

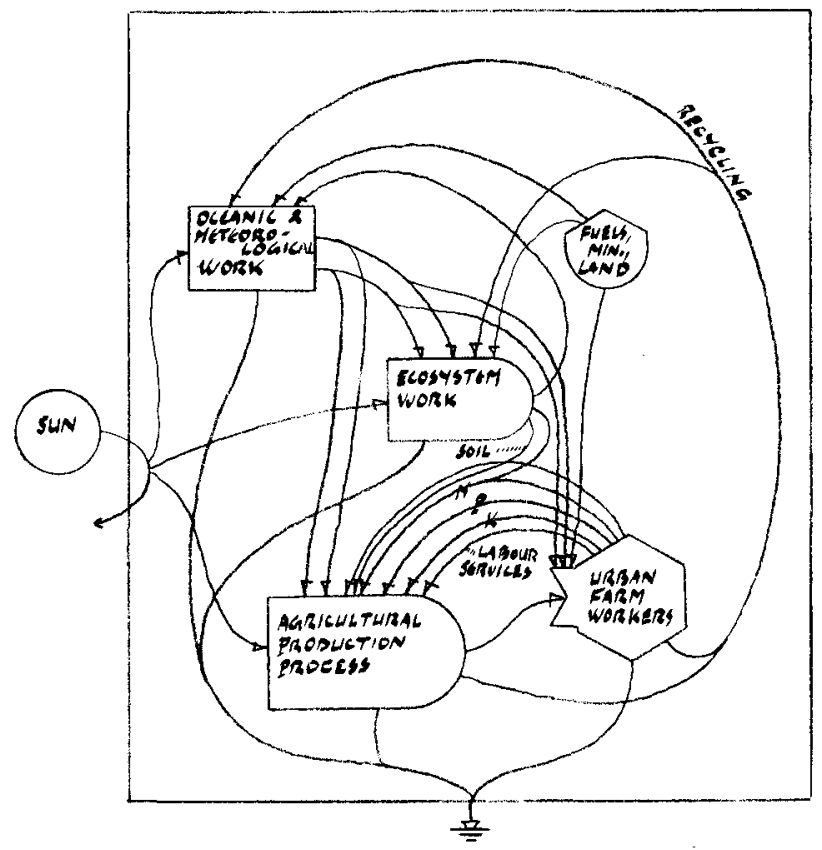

FIG. 2. Agricultural production process within the web of energy transformation processes (Odum, 1984).

formation processes, though in this ideal case only labour and services that are used directly on the farm are taken into account.

In reality, some of the inputs involve human labour; and some have to be paid for, at least indirectly - but not all of them. The first ones are purchased inputs (fuel, electricity, 
irrigation water, pesticide(s), fertilizers, and seed(s), in Fig. 1), whereas the other required ingredients (direct Sun, wind, rain, and soil) appear as indirect, and even unrecognized, environmental contributions to the economic products. So there are accompanying payments of money for some but not all inputs. Unpaid inputs constitute externalities from an economic viewpoint. In this case, they are defined as energy externalities - namely inputs which are not included in the prices, but which are in the process. In other words, their works are not paid for-they are not included in the prices-but they take part in the product. Therefore, evaluating energy externalities means considering indirect environmental contributions to the main economy.

The word 'energy' appears to outline the fact that one has to evaluate those effects on an equivalent ability-to-dowork. No cash value is placed on them, but they carry energetic meanings (cf. Fig. 3). However, one must be careful in counting them, for some flows are mere by-products of the same source or process. In particular, this is the case when several solar-generated inflows converge in a production process. They are evaluated separately first, but only the largest one (e.g. rain) is counted. 'The others were byproducts of the same initial solar energy in which less of the original total reached the area' (Odum, 1984). Reconvergence of by-product flows in a web is shown in Fig. 4.

In contrast one must retain a dual calculation for purchased resources, for in this case there are two input energy sources to be evaluated. Thus on one hand there is the energy embodied in the commodity itself, and on the other there is the enmergy* of the human service involved, of which the unit is the enmjoule* (enmJ). Enmergy is assigned to services in proportion to the money paid, depending on the monergy of the country, namely the ratio of its enmergy flow to dollar flow (Odum \& Odum, 1983;

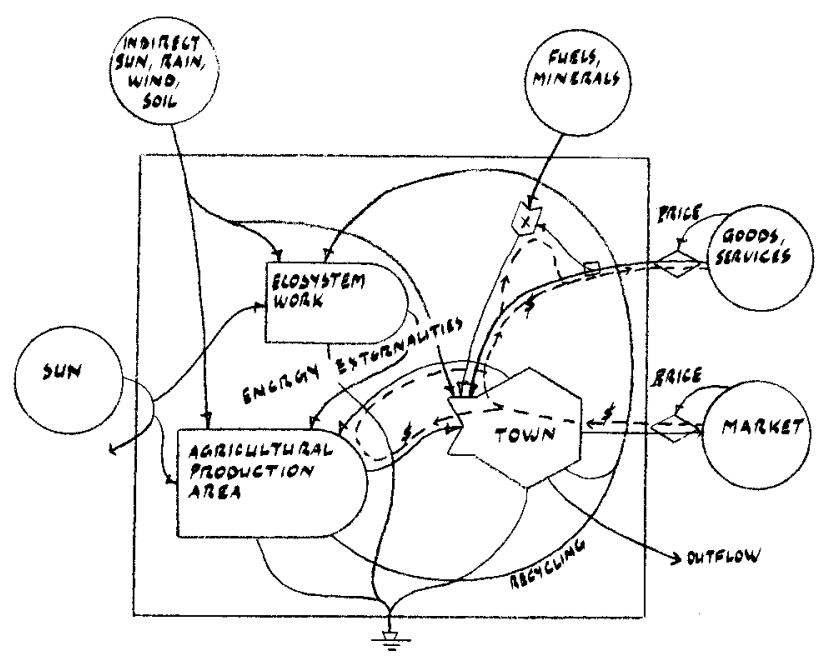

FIG. 3. Agro-ecosystem. Energy externalities (unpaid inputs) versus purchased inputs.

* 'Emergy' and 'emjoule' had been proposed as terms but were soon changed to avoid confusion - see the chapter (pp. 337-69) by Howard T. Odum, entitled 'Enmergy in Ecosystems', in our Ecosystem Theory and Application (John Wiley \& Sons, ChichesterNew York-Brisbane-Toronto-Singapore: $x v+445$ pp., illustr. 1986). -Ed.

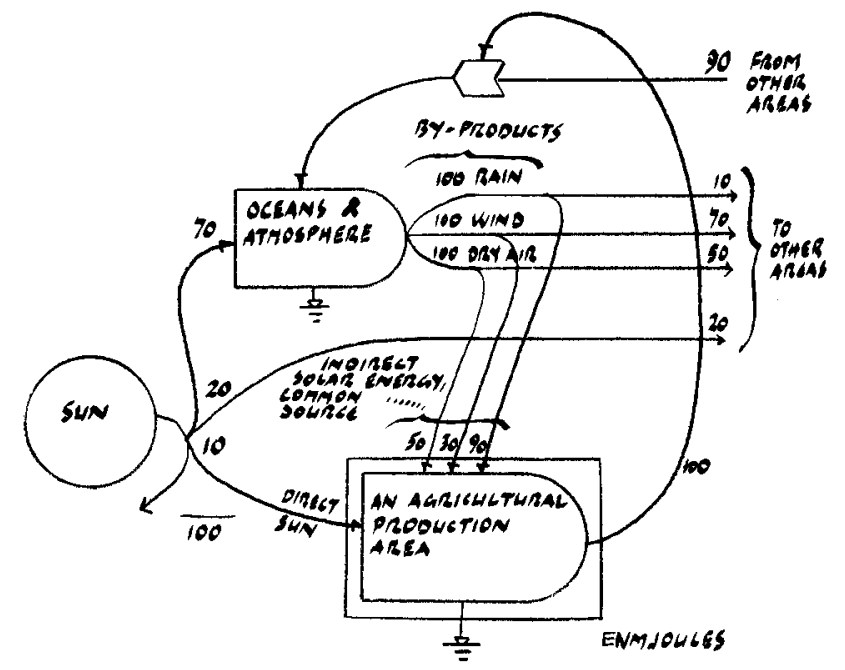

FIG. 4. Reconvergence of by-product flows in a web of energy transformation processes (Odum, 1984).

Pillet \& Odum, 1984). Monergy has been proposed by G. Pillet and H.T. Odum as a new name for enmergy $/ \$$ ratio. The assumption is made that the buying power of the money in a country, as measured by the gross national product, is due to the utilization of all of the energy available (energy externalities included), and that the two are proportional.

Now, if an agro-ecosystem contributes to a large part of the total enmergy of the economy, then its contribution to services has to be subtracted from the services which are going to be counted as inputs to that subsystem (Odum, 1984). This is not the case here.

\section{ENERGy ANALysis of the ENVIRONMENTAL ROLE IN GENEVA WINE INDUSTRY}

Typical energy analysis of the environmental role in agriculture is that from Odum \& Odum (1983) of United States industrial corn (maize), using data from Pimentel (1979) and adding environmental and service inputs. Energy analysis of sheep production in New Zealand $\dagger$, and of Louisiana sugar-cane, are pioneer studies as well (see Odum \& Odum, 1979, 1983; Odum, 1984).

As an example, energy analysis of Louisiana sugar-cane and sugar processing to ethanol was made, using data from Ricaud (1980) and adding environmental and service inputs (Odum \& Odum, 1983). Transformity of sugar, bagasse, and ethanol, were obtained ('transformity' having been proposed by D. Scienceman \& H.T. Odum as a new name for energy transformation ratio [ETR], see Fig. 5). Thus, one main result of such a case-study is to provide typical energy transformation ratios, and then to calculate indices and to discuss inferences according to that case. The task is the same as regards the present study.

The total area of vineyards in the Canton de Genève, Switzerland, is 1291 ha (ASS, 1984), constituting $9.13 \%$ of all Swiss vineyards. In 1983, the yield of must (unfermented grape-juice) was $51,422 \mathrm{hl}$, which was $8.86 \%$ of the total must produced in the country.

$\dagger$ A referee adds the case 'of Brazilian sugar-cane-alcohol (just published in Brazil)'.-Ed. 


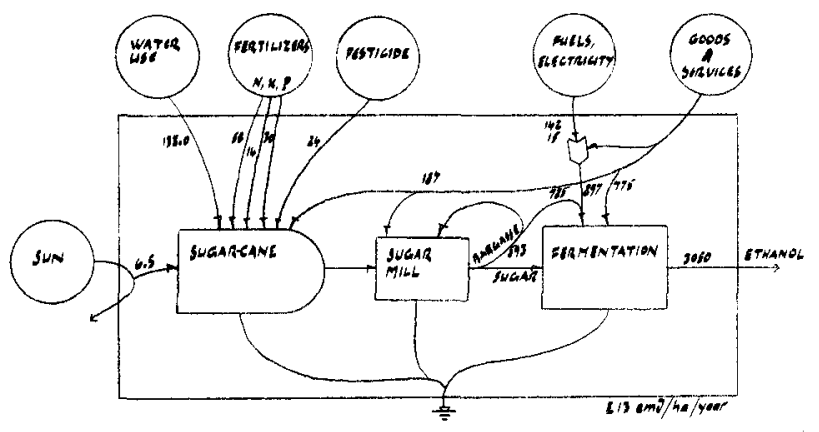

FIG. 5. Louisiana sugar-cane and sugar processing to ethanol (Odum \& Odum, 1983).

Energy analysis of Geneva vineyard production and further processing to wine is presented here, the data used being from Odum \& Odum (1983), Pillet \& Odum (1984), Vazquez-Duhalt (1984), and J. Schwarzenbach (pers. comm. from Service Romand de Vulgarisation Agricole, Lausanne, Switzerland).

Most of the energy is supplied as or by solar energy by-products (e.g. rains), as well as by purchased inputs such as phosphate $\left(\mathrm{P}_{2} \mathrm{O}_{5}\right)$, potassium $\left(\mathrm{K}_{2} \mathrm{O}\right)$, and nitrogen $(\mathrm{N})$. Fuels used directly as well as service inputs have been taken into account. The fermentation process needs sugar, electricity, hot water (indirectly), and services. The bines (flexible shorts) have been evaluated on the same energy-basis as reusable waste products. Energy evaluation has been included to provide solar transformity of grapes as well as of wine as a final product. Energy flows in one hectare have been evaluated, with Fig. 6 providing the energy diagram and the calculations shown in Table I.

\section{DISCUSSION}

When the diagram has been completed with enmergy flows, one can build an aggregated three-armed diagram, calculated for the main flows (Fig. 7). Then useful ratios may be calculated to help interpretation (Odum \& Odum, 1983).

\section{Net Enmergy Yield and Enmergy Investment Ratios}

The net enmergy yield ratio is the enmergy of the output (Y) divided by the enmergy of the inputs to the process which is fed back from the economy $(F)$. Definition of the net enmergy yield ratio is depicted in Fig. 8. The ratio characterizing Geneva wines is 1.04 , while that of Louisiana sugar-cane production and further processing to etha$\mathrm{nol}$ is $\mathbf{1 . 0 5}$.

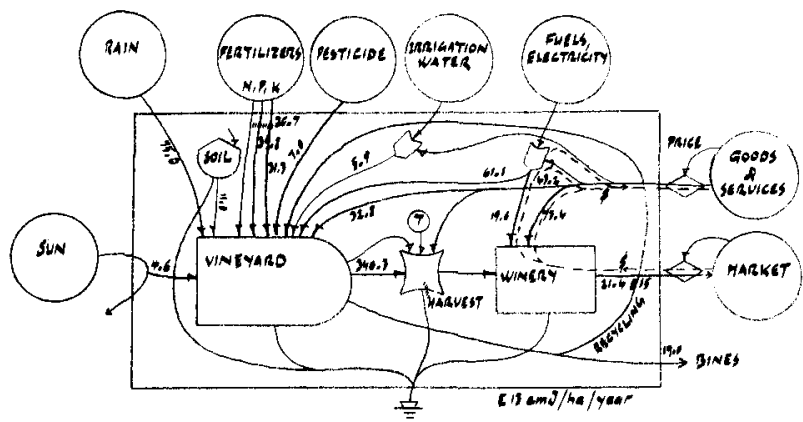

FIG. 6. Energy diagram of Geneva vineyard production, and further processing to wine.
TABLE I

Energy Flows in One Hectare of Vineyard Production and Further Processing to Wine, Geneva Canton.

\begin{tabular}{|c|c|c|c|c|}
\hline $\begin{array}{l}\text { Foot- } \\
\text { notes }\end{array}$ & Type of energy & $\begin{array}{c}\text { Aclual Energy } \\
J / y\end{array}$ & $\begin{array}{l}\text { Solar } \\
\text { Transformity } \\
\text { eninJ } / y\end{array}$ & $\begin{array}{c}\text { Enmergy } \\
\text { E } 13 \text { enm } / y\end{array}$ \\
\hline $\begin{array}{r}1 \\
2 \\
3 \\
4 \\
5 \\
6 \\
7 \\
8 \\
9 \\
10 \\
11 \\
12 \\
13 \\
14 \\
15 \\
16 \\
17 \\
18 \\
19 \\
20 \\
21\end{array}$ & $\begin{array}{l}\text { Direct Sun } \\
\text { Rain } \\
\text { Soil used up } \\
\text { Organic matter } \\
\text { Irrigation water } \\
\text { Nitrogen }(\mathrm{N}) \\
\text { Potassium }\left(\mathrm{K}_{2} \mathrm{O}\right) \\
\text { Phosphate }\left(\mathrm{P}_{2} \mathrm{O}_{5}\right) \\
\text { Pesticide } \\
\text { Direct fuels } \\
\text { Steel in machinery } \\
\text { Iron wires, stakes } \\
\text { Services } \\
\text { Grapes yield } \\
\text { Sugar added } \\
\text { Electricity } \\
\text { Water } \\
\text { Capital } \\
\text { Services } \\
\text { Wines yield } \\
\text { Bines (when } \\
\text { burned) }\end{array}$ & $\begin{array}{c}4.6 \text { E } 13 \\
5.0 \text { E } 10 \\
17.6 \text { E } 8 \\
1.02 \text { E } 9 \\
3.95 \text { E } 8 \\
15.2 \text { E } 7 \\
11.93 \text { E } 7 \\
9.61 \text { E } 6 \\
10.64 \text { E } 8 \\
9.25 \text { E } 9 \\
1.81 \text { E } 7 \\
3.25 \text { E } 7 \\
\$ 6 \mathrm{E} 3 / \mathrm{ha} / \mathrm{y} \\
4.74 \text { E } 10 \\
6.66 \text { E } 9 \\
1.23 \text { E } 9 \\
1.11 \text { E } 8 \\
\$ 2.3 \mathrm{E} 4 / \mathrm{ha} / \mathrm{y} \\
\$ 1.02 \mathrm{E} 3 / \mathrm{ha} / \mathrm{y} \\
3.3 \text { E } 10 \\
2.84 \text { E } 10\end{array}$ & 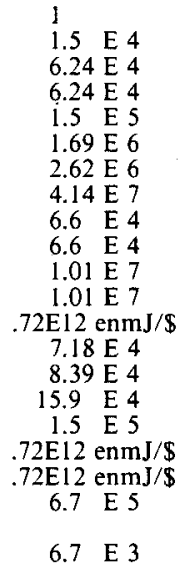 & $\begin{array}{c}4.6 \\
75.0 \\
11.0 \\
6.4 \\
5.9 \\
26.7 \\
31.3 \\
39.8 \\
7.0 \\
61.1 \\
18.3 \\
32.8 \\
43.2 \\
340.3 \\
55.9 \\
19.6 \\
1.7 \\
16.6 \mathrm{E} 15 \\
73.4 \\
21.4 \mathrm{E} 15 \\
19.0\end{array}$ \\
\hline
\end{tabular}

Footnotes to Table I

1. Direct Sun: $\left(1.1 \mathrm{E} 6 \mathrm{kcal} / \mathrm{m}^{2} / \mathrm{y}\right)\left(1 \mathrm{E} 4 \mathrm{~m}^{2} / \mathrm{ha}\right)(4186 \mathrm{~J} / \mathrm{kcal})=$ 4.6 E $13 \mathrm{~J} / \mathrm{ha} / \mathrm{y}$ (Odum \& Odum, 1983; Pillet \& Odum, 1984). By definition, solar transformity of direct Sun is 1 .

2. Rain (water evapotranspired): $1020 \mathrm{~mm} / \mathrm{y}$ (Geneva) (ASS, $1984) ;\left(1.02 \mathrm{~m}^{3} / \mathrm{m}^{2} / \mathrm{y}\right)\left(1 \mathrm{E} 4 \mathrm{~m}^{2} / \mathrm{ha}\right)\left(1 \mathrm{E} 6 \mathrm{~g} / \mathrm{m}^{3}\right)(4.9 \mathrm{~J} / \mathrm{g})=$ $4.998 \mathrm{E} 10 \mathrm{~J} / \mathrm{ha} / \mathrm{y}$. Transformity is for chemical potential energy in rain over land (Odum \& Odum, 1983).

3. Soil used up. Total area: 1291 ha (1983) (ASS, 1984); erosion rate (estimation) $; 260 \mathrm{~g} / \mathrm{m}^{2} / \mathrm{y}$ (Odum \& Odum, 1983 ; Pillet \& Odum, 1984); no successional area; organic fraction 0.03 (guess); $\left(260 \mathrm{~g} / \mathrm{m}^{2} / \mathrm{y}\right)\left(1 \mathrm{E} 4 \mathrm{~m}^{2} / \mathrm{ha}\right)(0.03$ organic) $(5.4 \mathrm{kcal} / \mathrm{g})$ $(4186 \mathrm{~J} / \mathrm{kcal})=17.63 \mathrm{E} 8 \mathrm{~J} / \mathrm{ha} / \mathrm{y}$. Transformity in topsoil formation and storage (Odum \& Odum, 1983).

4. Organic matter added: (1500 kg/ha/y) (1 E $3 \mathrm{~g} / \mathrm{kg})(0.03$ organic) $(5.4 \mathrm{kcal} / \mathrm{g})(4186 \mathrm{~J} / \mathrm{kcal})=1.02 \mathrm{E} 9 \mathrm{~J} / \mathrm{ha} / \mathrm{y}(\mathrm{CF}, 1983$; Odum \& Odum, 1983). Transformity of organic matter in topsoil storage (Odum \& Odum, 1983).

5. Irrigation water. Water added (irrigation): $40 \mathrm{~mm} / \mathrm{ha} / \mathrm{y}$ upon $1 / 5$ of the vineland area (Vazquez-Duhalt, 1984). Public Utilities supply irrigation water; energy used is estimated to 1203 $\mathrm{kcal} / \mathrm{mm} / \mathrm{ha}$ (Pimental et al., 1973; Vazquez-Duhalt, 1984); (1 $\left.\mathrm{E} 4 \mathrm{~m}^{2}\right)(0.2)(0.04 \mathrm{~m} / \mathrm{ha} / \mathrm{y})(4.94 \mathrm{~J} / \mathrm{g})\left(1 \mathrm{E} 6 \mathrm{~g} / \mathrm{m}^{3}\right)=39.52 \mathrm{E} 7$ $\mathrm{J} / \mathrm{ha} / \mathrm{y}$. Transformity in irrigation water (Odum, 1984); that is, including indirect fuels in service.

6. Nitrogen (N): $70 \mathrm{~kg} / \mathrm{ha} / \mathrm{y}$ (Vazquez-Duhalt, 1984); $2170 \mathrm{~J} / \mathrm{g}$ (Odum \& Odum, 1983); (70 E $3 \mathrm{~g} \mathrm{~N})(2.17 \mathrm{E} 3 \mathrm{~J} / \mathrm{g})=151.9 \mathrm{E} 6$ $\mathrm{J} / \mathrm{ha} / \mathrm{y}$. Transformity is for $\mathrm{N}$ (Odum \& Odum. 1983).

7. Potassium $\left(\mathrm{K}_{2} \mathrm{O}\right): 170 \mathrm{~kg} / \mathrm{ha} / \mathrm{y}$ (Vazquez-Duhalt, 1984); 702 $\mathrm{J} / \mathrm{g}$ (Odum \& Odum, 1983); Gibbs free energy* in refined potash (energy evaluation of potash production from the Dead Sea works during 1980-81);(170 kg/ha/y K $2 \mathrm{O})(1 \mathrm{E} 3 \mathrm{~g} / \mathrm{kg})$ $(702 \mathrm{~J} / \mathrm{g})=11.934 \mathrm{E} 7 \mathrm{~J} / \mathrm{ha} / \mathrm{y}$. Transformity is for refined $\mathrm{KCl}$ based on all inputs (Odum \& Odum, 1983).

8. Phosphate $\left(\mathrm{P}_{2} \mathrm{O}_{5}\right): 60 \mathrm{~kg} / \mathrm{ha} / \mathrm{y}$ (Vazquez-Duhalt, 1984) as $46 \%$ triple phosphate; $348 \mathrm{~J} / \mathrm{g}$ (Odum \& Odum, 1983); Gibbs free energy* in the phosphorus concentration relative to prevailing solutions from which phosphorus was first concentrated by shellfish to $1 \%$ and further by swamps solution to $10 \%$ (solution equilibrium with solid phosphate taken as $1 \mathrm{ppm}) ;(60$ $\mathrm{kg} / \mathrm{ha} / \mathrm{y})(1 \mathrm{E} 3 \mathrm{~g} / \mathrm{kg})(0.46)(348 \mathrm{~J} / \mathrm{g})=9.6118 \mathrm{E} 6 \mathrm{~J} / \mathrm{ha} / \mathrm{y}$. Transformity in phosphate rock (Odum \& Odum, 1983).

* In answer to our query about this the Author refers to the account of Odum \& Odum (1983). - Ed. 
9. Pesticide: $70 \mathrm{~kg} / \mathrm{ha} / \mathrm{y}$ (Vazquez-Duhalt, 1984); $15 \%$ of concentration (Green \& McCulloch, 1976); 24.2 E $3 \mathrm{kcal} / \mathrm{kg}$ (Pimentel et al., 1973), or oil equivalents used in pesticide manufacture, $2.87 \mathrm{E} 5 \mathrm{kcal}$ fuel/ha (Pimentel, 1979; Odum \& Odum, $1983) ;(70 \mathrm{~kg} / \mathrm{ha} / \mathrm{y})(0.15)(24.2 \mathrm{E} 3 \mathrm{kcal} / \mathrm{kg})(4186 \mathrm{~J} / \mathrm{kcal})=$ $10.6366 \mathrm{E} 8 \mathrm{~J} / \mathrm{ha} / \mathrm{y}$. Transformity of fuel (Odum \& Odum, 1983).

10. Direct fuels: $2,204.5 \mathrm{E} 3 \mathrm{kcal} / \mathrm{ha} / \mathrm{y}$ of motor fuels (VazquezDuhalt, 1984); $(2.21 \mathrm{E} 6 \mathrm{kcal} / \mathrm{ha} / \mathrm{y})(4186 \mathrm{~J} / \mathrm{kcal})=9.251 \mathrm{E} 9$ $\mathrm{J} / \mathrm{ha} / \mathrm{y}$. Transformity in liquid motor fuel (Odum \& Odum, 1983).

11. Steel in machinery: $200 \mathrm{~kg}$ steel in machinery $/ \mathrm{ha} / \mathrm{y}(\mathrm{J}$. Schwarzenbach, pers. comm. 1985); 90.4 E $6 \mathrm{~J} / \mathrm{t} \mathrm{Fe} \mathrm{(Odum} \mathrm{\&}$ Odum 1983); $(0.26 \mathrm{t})(94 \mathrm{E} 6 \mathrm{~J} / \mathrm{t} \mathrm{Fe})=1.808 \mathrm{E} 7 \mathrm{~J} / \mathrm{ha} / \mathrm{y}$. Transformity in refined iron and steel (Odum \& Odum, 1983).

12. Iron wires and stakes: $60 \mathrm{~kg}$ of iron wires and $300 \mathrm{~kg}$ of iron stakes /ha/y (J. Schwarzenbach, pers. comm. 1985); 90.4 E 6 $\mathrm{J} / \mathrm{t} \mathrm{Fe}$ (Odum \& Odum, 1983); (0.36 t) (90.4 E $6 \mathrm{~J} / \mathrm{t} \mathrm{Fe})=3.254$ E $7 \mathrm{~J} / \mathrm{ha} / \mathrm{y}$. Transformity in refined iron and steel (Odum \& Odum, 1983).

13. Services in vineyard and in harvest: 1000 man-hours/ha/y (Vazquez-Duhalt, 1984); 15 E 3 SFR/ha/y (estimation 1983; CF, 1983; ASS, 1984). Swiss monergy (enmergy/\$ ratio) 1982 used instead of transformity: 0.72 E $12 \mathrm{enmJ}(\$$ (Pillet \& Odum, 1984). Exchange rate, SFR 2.50 [1983].

14. Vine grapes yield: $150 \mathrm{q} /$ ha (Station Cantonale de Viticulture, $1985) ; 100 \mathrm{~g}$ grapes $=75.5 \mathrm{kcal}$ (Vazquez-Duhalt, 1984); $(150$ $\left.\mathrm{q}^{*} / \mathrm{ha} / \mathrm{y}\right)(1 \mathrm{E} 5 \mathrm{~g} / \mathrm{q})(0.755 \mathrm{kcal} / \mathrm{g})(4186 \mathrm{~J} / \mathrm{kcal})=4.74 \mathrm{E} 10$ $\mathrm{J} / \mathrm{ha} / \mathrm{y}$. Transformity: (all inputs in enm J) / (output $\mathrm{J}$ ):

$\underline{(75+11+6.4+5.9+26.7+31.3+39.8+7+61.1+32.8+43.2) \mathrm{E} 13 \mathrm{enm} J}$ $4.74 \mathrm{E} 10 \mathrm{~J}$

$=7.18 \mathrm{E} 4 \mathrm{enm} J / J$.

15. Sugar added in fermentation process. Mean volume over three years $(1981,1983,1984): 3.5 \mathrm{~kg} / \mathrm{hl}$; usual volume is $2 \mathrm{~kg} / \mathrm{hl}$; in fact, fermentation process only requires $0.5 \mathrm{~kg} / \mathrm{hl}$ of must ( $\mathrm{J}$. Schwarzenbach, pers. comm. 1985). Must yield: 113.09 $\mathrm{hl} / \mathrm{ha} / 1983$ (SCS, 1984); (113.09 hl/ha/y) $(3.5 \mathrm{~kg} / \mathrm{hl})(4020$ $\mathrm{kcal} / \mathrm{kg})(4186 \mathrm{~J} / \mathrm{kcal})=6.66 \mathrm{E} 9 \mathrm{~J} / \mathrm{ha} / \mathrm{y}$. Transformity in Louisiana sugar-cane (Odum \& Odum, 1983).

16. Electricity: $3 \mathrm{kWh} / \mathrm{hl}$ (J. Schwarzenbach, pers. comm. 1985); $(113.09 \mathrm{hl} / \mathrm{ha} / \mathrm{y})(3 \mathrm{kWh} / \mathrm{hl})(3.6 \mathrm{E} 6 \mathrm{~J} / \mathrm{kWh})=1.23 \mathrm{E} 9 \mathrm{~J} / \mathrm{ha} / \mathrm{y}$. Transformity of hydroelectricity (Odum \& Odum, 1983).

17. Water: In volume, two times the must yield (J.Schwarzenbach, pers. comm. 1985); (113.09 hl must/ha/y) $(2 \mathrm{hl} \mathrm{water} / \mathrm{hl}$ must) $(1 \mathrm{E} 5 \mathrm{~g} / \mathrm{q})(4.9 \mathrm{~J} / \mathrm{g})=1.11 \mathrm{E} 8 \mathrm{~J} / \mathrm{ha} / \mathrm{y}$. Transformity of water supplied by Public Utilities.

18. Capital in bare land, machinery, and winery, flow per year over 25 years: SFR $522 / \mathrm{hl}$ wine/y (J. Schwarzenbach, pers. comm 1 1985); 1001 of must $=981$ of industrial wine $) ;(113.09$ hl must $/ \mathrm{ha} / \mathrm{y})(0.98 \mathrm{hl}$ wine/hl must) (SFR 522/hl) $=$ SFR $57,852 / \mathrm{ha} / \mathrm{y}=\$ 23,140.93 / \mathrm{ha} / \mathrm{y}$. Swiss monergy used instead of transformity (Pillet \& Odum, 1984).

19. Services: 1.7 man-hour/hl/y; or, SFR $22.95 / \mathrm{hl} / \mathrm{y}$ (J. Schwarzenbach, pers. comm. 1985); (113.09 hl must/ha/y) $(0.98 \mathrm{hl}$ wine $/ \mathrm{hl}$ must) (SFR 22.95/hl) = SFR 2,543.51/ha/y = $\$ 1017.40 / \mathrm{ha} / \mathrm{y}$. Swiss monergy used instead of transformity (Pillet \& Odum, 1984).

20. Wines yield: $0.98 \mathrm{hl}$ wine/hl must (J. Schwarzenbach, pers. comm. 1985); $100 \mathrm{hl}=6.9 \mathrm{E} 6 \mathrm{kcal}$ (Deleage et al., 1977); $(113.09 \mathrm{hl} \mathrm{must} / \mathrm{ha} / \mathrm{y})(0.98 \mathrm{hl}$ wine $/ \mathrm{hl}$ must $) ;(6.9 \mathrm{E} 4 \mathrm{kcal} / \mathrm{hl})$ $(4186 \mathrm{~J} / \mathrm{kcal})=3.20 \mathrm{E} 10 \mathrm{~J} / \mathrm{ha} / \mathrm{y}$. Transformity:

$\frac{(340.3+55.9+19.6+1.7+1660+73.4) \mathrm{E} 13 \mathrm{enmJ}}{3.20 \mathrm{E} 10 \mathrm{~J}}$

$=6.7 \mathrm{E} 5 \mathrm{enmJ} / \mathrm{J}$.

21. Bines as a waste product. Bines yield: $2.1-4.5 \mathrm{t} / \mathrm{ha} / \mathrm{y}$ (Nataliccho \& Semeza, 1981); 1.5 t dry wood to burn; in general, bines are recycled within the system (J. Schwarzenbach, pers.

* In answer to our query about this the Author refers to the account of Odum \& Odum (1983). - Ed.

${ }^{*} \mathrm{q}=$ quintal $=100 \mathrm{~kg} . \quad \mathrm{hl}=$ hectolitre $=100$ litres.

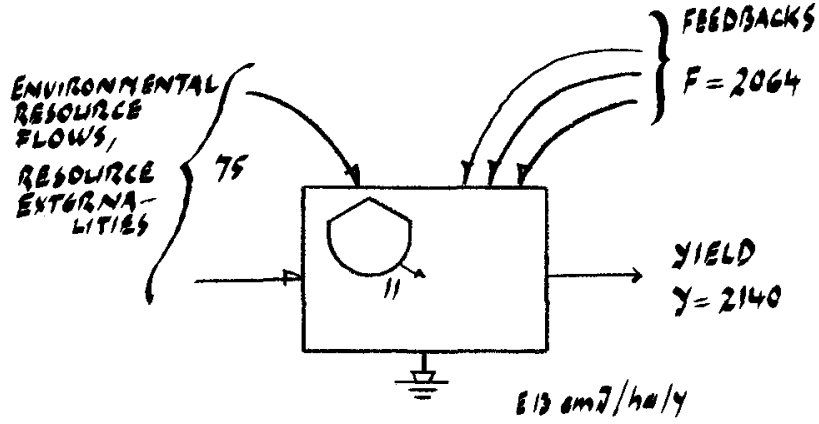

FIG. 7. Aggregated three-armed diagram calculated from data in Table I.

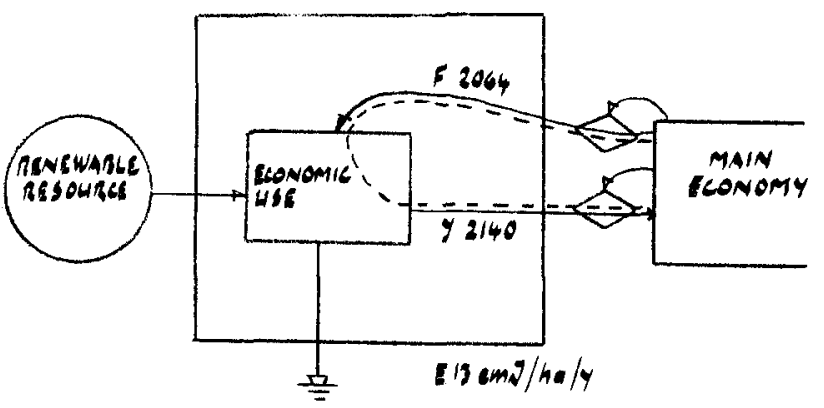

FIG. 8. Diagram defining the Net Enmergy Yield Ratio $(Y / F)$.

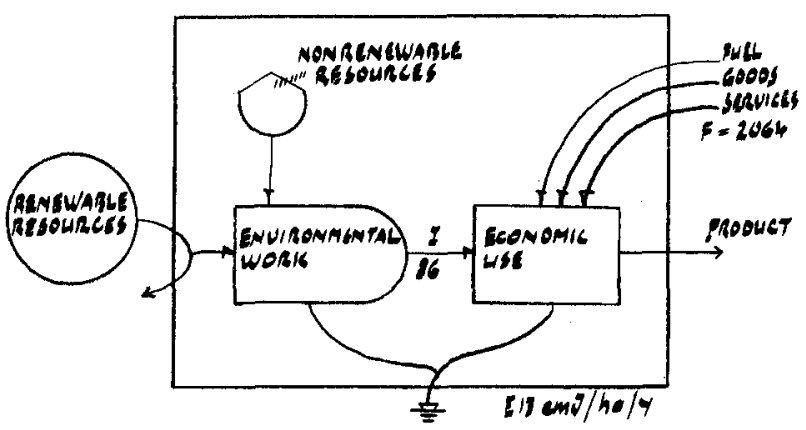

Fig. 9. Diagram defining the Enmergy Investment Ratio and the Enmergy Externality Ratio. Enmergy Investment Ratio $=F / I$; Enmergy Externality Ratio $=I /(I+F)($ Odum \& Odum, $1983 ;$ Pillet \& Odum, 1984).

comm. 1985); $4523 \mathrm{kcal} / \mathrm{kg}$ or dry bines, if burned down (Vazquez-Duhalt, 1984); (1.5 E $3 \mathrm{~kg} / \mathrm{ha} / \mathrm{y})(4523 \mathrm{kcal} / \mathrm{kg})$ $(4186 \mathrm{~J} / \mathrm{kcal}=2.84 \mathrm{E} 10 \mathrm{~J} / \mathrm{ha} / \mathrm{y}$. Transformity is for softwood (Odum \& Odum, 1983).

The enmergy investment ratio, defined in Fig. 9, is the ratio of the enmergy fed back from the economy to the enmergy inputs from the environment. Ratio characterizing wine production in the Canton of Geneva is 24 . It is 25 for US agriculture, 21 for ethanol production in Louisiana. This ratio is useful in comparing alternatives, as it indicates whether the process is economic as a utilizer of the economy's investments in comparison with alternatives. The world ratio in 1980 was 1.4 , and US ratio about 6.6 or even up to 8 (Odum \& Odum, 1983). 
Some systems do not really supply primary sources to the economy, but may have competitive net enmergy yield ratios. This is the case as regards wine production in the Geneva region, to the extent that wine appears as a final product. A competitive enmergy investment ratio may indicate a good secondary source when a system has a high net enmergy yield ratio, which is not the case here.

Yet, the energy analysis of subsystems may be useful for evaluating the degree of industrialization (which is the case here), for anticipating success of subsystems that are being considered for development (drawing more environmental energies than purchased ones may increase efficiency of some processes), and for evaluating contributions of the environment, namely energy externalities.

\section{Energy Externality Ratio}

In the case which we consider here, the ratio of use that is free is approximately $\mathrm{I} /(\mathrm{I}+\mathrm{F})=.04$ (see Fig. 9 ). It is less than the ratio calculated for Switzerland (.16; Pillet \& Odum, 1984).

Energy externality as such (I) may be evaluated to SFR $18,000 /$ ha/year, according to the monergy of the free environmental contribution to the Swiss economy (.12 E 12 enmJ $/ \$$; Pillet \& Odum, 1984). This is less than the annual capital flow/ha (about SFR 58,000), and a little more than the flow of services spent ha/year in vineyard and harvest (SFR 15,000). As regards the total amount of services spent in Canton of Geneva wine production, one could say that energy externality contributes $30 \%$ of the works, or $15 \%$ if the capital flow is taken into account.

In general, this is more than economists usually put on environmental services or natural resources (from $1 \%$ to $2.5 \%$ ), arguing that economic products are to the extent of 97.5 or even $99.0 \%$ made of embodied human labour only (Kolm, 1985).

This study of the environmental role in an economic subsystem by means of energy externality analysis shows that external, environmental contributions to the economy have to be taken into account when we are concerned with the vitality of economic systems in the full context of their environment.

\section{ACKNOWLEDGEMENT}

Part of this research was done when the Author was Adjunct Research Associate, Department of Environmental Engineering Sciences, and Center for Wetlands, University of Florida, Gainesville, Florida, USA. Thanks are due to Professor Howard T. Odum for substantial contributions in the preparation of this study. Financial support by the Swiss National Science Foundation under Grants Numbers $81.079 .0 .83 \& 1.378-0.86$ is gratefully acknowledged.

\section{SUMMARY}

There is a need today for accurate understanding of the relationships between economic activities and the environmental realm. In particular, it is urgent from an economic viewpoint to put quantitative meanings upon external, environmental contributions to the economy. Energy analysis and energy externality evaluation procedures are useful in this respect.

This paper focuses on the analysis of an economic subsystem, in order to evaluate the environmental role by means of the energy externality procedure. Energy analysis of the Geneva Canton's vineyard cultivation and wine production is presented as a case-study, and comparisons are made with other, similar agro-ecosystems. Energy externality is evaluated, and useful ratios are duly calculated. New or unfamiliar terms are explained.

With a rather high enmergy investment ratio, similar to that of US agriculture, wine production in the Geneva Canton shows that very large amounts of enmergy are fed back from the economy in comparison with enmergy inputs from the environment. In this respect, the energy externality ratio (or, the ratio of use that is free) is rather low (.04). It is one quarter of that calculated for the main economy of Switzerland. Energy externality as such has been evaluated to SFR $18,000 / \mathrm{ha} /$ year. This is a little more than the flow of services spent in one hectare/year in vineyard and harvest. However, it is more than economists usually place on environmental services.

\section{REFERENCES}

ASS (1984). Annuaire Statistique de la Suisse. Office fédéral de la statistique, Birkhäuser, Bâle, Switzerland: ix $+658 \mathrm{pp}$.

CF (1983). Enquête sur les frais de production en viticulture. Commission fédérale du prix de revient des raisins et du vin, Lausanne, Switzerland: 3 tables.

Deleage, J.-P., Nandin, N. Sauget \& Souchon, C. (1977). Analyse éco-énergétique du système agricole français. CEGERMA, Paris, France: 33 pp.

GreEN, M.B. \& MCCulloch, A. (1976). Energy considerations in the use of herbicides. J. Sci. Food Agric., 27, pp. 95-100.

Kolm, S.C. (1985). Le contrat social libéral. Presses Universitaires de France, Paris, France: 485 pp.

Nataliccho, E. \& Semeza, C. (1981). Possible Production, Recovery Techniques, Present and Alternative Uses of Agricultural Byproducts. C.N.R. - Progetto finalizzato meccanizzasione agricola, Roma, Italy: Quaderno no. 23. [not available for checking].

ODum, H.T. (1983). Systems Ecology: An Introduction. WileyInterscience, New York, NY, USA: 678 pp., illustr.

ODUM, H.T. (1984). Energy analysis of the environmental role in agriculture. Advanced Series in Agriculture (Springer-Verlag, Berlin), Vol. 14, pp. 24-51.

ODUM, H.T. \& ODum, E.C. (1979). Energy system of New Zealand and the use of embodied energy for evaluating benefits of international trade. Proceedings of Energy Modelling Symposium, New Zealand Ministry of Energy, Christchurch, New Zealand, (Technical Publication No. 7). [Not available for checking.]

ODum, H.T. \& ODum, E.C. (1983). Energy Analysis Overview of Nations. (WP-83-82.) International Institute for Applied Systems Analysis, Laxenburg, Austria: 469 pp., illustr.

Pillet,G. \& Odum, H.T. (1984). Energy externality and the economy of Switzerland. Schweiz. Zeitschrift für Volkswirtschaft und Statistik / Revue Suisse d'économie politique et de statistique, 120, pp. 409-35.

Pillet, G. \& Odum, H.T. (1987). E $E^{3}-$ Energie, Ecologie, Economie. Georg \& Cie SA, Geneva, Switzerland: xvi + 299 pp., illustr.

Pimentel, D. (1979). Energy in agriculture. Pp. 73-106 in Food, Climate, and Man (Eds M.R. Biswas \& A.K. Biswas). J. Wiley \& Sons, New York, NY, USA: [not available for checking]. 
Pimentel, D., Hurd, L.E., Bellotti, A.C., Foster, J.J., OKa, I.N., SHOKES, O.D. \& WhITMAN, R.J. (1973). Food production and the energy crisis. Science, 182, pp. 443-50.

RiCAUD, R. (1980). Energy input and output for sugar cane in Louisiana. Pp. 135-6 in Handbook of Energy Utilization in Agriculture (Ed. D. PIMENTEL). CRC Press, Boca Raton, Florida, USA: [not available for checking].
SCS (1984). Annuaire statistique du Canton de Genève. Service cantonal de statistique, Genève, Switzerland: $316 \mathrm{pp}$.

Station Cantonale de Viticulture [et d'CEnologie] (1985). Rapport d'activité-Essais 1984, Geneva, Switzerland: 17 pp.

VAZQUEZ-DUHALT, R. (1984). Genève: agriculture et énergie. Mémoire. CUEH, Université de Genève, Switzerland: 173 pp., illustr. 